\title{
MIÉRT A HELY ÉS A METAFORA?
}

Miért a hely és a metafora? Az első kérdés, ami megfogalmazódhat bennünk, miután először átlapozzuk Fejős Zoltán kötetét, hogy a kötet címében e két szó miért kap ilyen kiemelt helyet. A választás oka nem magától értetődő, de feltétlenül figyelmet érdemel.

Fejős Zoltán három cikluson keresztül, 1997-2013-ig vezette a Néprajzi Múzeumot, s ahogy a bevezetőben írja, kollégáival fáradhatatlanul próbáltak utakat találni az „,igazi” múzeumhoz (Fejős, 9.). 2002-2003 fordulóján kezdeményezésükre indult el a Ma-Dok program, melynek fö célja a múzeumi jelenkutatás és hálózatépítés volt. 1989-től vizsgálták a ,jelent”. S ugyan a kutatók szemszögéből a módszertanok kidolgozása, a hálózatépítés és a kutatás elsődleges fontossággal bírt, Fejős arról számol be, hogy „.... minisztérium képviselői számára az egész vállalkozásból az volt a legfontosabb, hogy a múzeumok gyüjteményei mai anyagokkal gyarapodjanak. Ezen kifejezetten tárgybeszerzést kell érteni, a kortárs anyag föltárása, a kutatómunka vagy akár képi, illetve szöveges dokumentáció ebbe a felfogásba nem vagy csak nehezen fért bele." (Fejős, 39.) Pedig, ahogy másfélszáz oldallal később megjegyzi, „(...) túl sok a tárgy, kevés a módszer” (Fejős, 196.).

A tíz éven keresztül sikerrel müködő program 2012-től nem kapott több financiális támogatást. Ez az év egybeesik Fejős távozásával is a Néprajzi Múzeum éléről, aki nyomban hozzá is látott, hogy tapasztalatait könyv formájában öszszegezze. A tizenhat évnyi múzeumvezetés, nem kevésbé a jelenkorkutatás területén elért eredmények, illetve a hazai pályaismeret összefogott, letisztult hangú munkát eredményeztek. Az Új helyek, új metaforák címü kötet elsősorban a társadalmi kérdésekkel foglalkozó, elsődlegesen az etnográfiai, kultúrtörténeti és történeti múzeumok müködését tárgyalja, de minden múzeumi szakember számára ajánlott és példaértékủ olvasmány. Kiváló, elfogultságoktól mentes összefoglalása annak, ami a kilencvenes évek végétől 2013-ig a múzeumi szakmában a jelenkorra vonatkozólag történt.

A szerző a bevezetésen, avagy a célok, keretek, módszerek ismertetésén és a befejező gondolatokon túl három nagy fejezetre bontja az általa vizsgált témát, azaz múzeum és jelenkor lehetséges közös halmazait. Az első az 1970-et követő negyven évet vizsgálva a magyarországi múzeumi jelenkutatás témáját járja körül annak problémáival és hiányosságaival is szembesítve az olvasót. Az ezt követő fejezet nemzetközi példákon, releváns nemzetközi szakirodalmon, múzeumok gyüjtési és kiállítási programján keresztül tárgyalja a múzeumi jelenkorkutatással, gyüjteményezéssel kapcsolatban felmerülő érvényes kérdéseket. A záró 
törzsfejezet a 21. század elején megjelenő múzeumi tendenciákat, „forró” témákat fejtegeti. Fejős rendkívül tág horizontot tár olvasója elé, úgy szakirodalmi jártasságát, mint szakmai tapasztalatát illetően. A múzeumi szakmát foglalkoztató vitákat a legjobb tankönyvekre jellemző tárgyiassággal ismerteti. A kötet nyolcvanoldalnyi irodalomjegyzékkel és hasznos mellékletekkel egészül ki, melyek között a szerző múzeumigazgatói időszaka idején felkeresett kül- és belföldi múzeumok és kiállítások listáját is megtaláljuk.

A mai múzeumokban a tárgyak szerepe visszaszorul, az élmény válik elsődlegessé. A múltat szemlélve is jelenünk aktuális kérdéseire szeretnénk inkább válaszokat kapni. Az, hogy mit mond számunkra az örökség, illetve, hogy mit fogadunk el kulturális örökségünk részeként, azaz miben látjuk meg az esélyét annak, hogy a minket követő nemzedékek számára üzenetértékkel bírjon majd korunkról, mind-mind inkább a jelenünkre vonatkozó kérdések, melyeket érdemes több nézőpontból, akár különféle tudományágakat segítségül hívva vizsgálni. Fejös gondosan körbejárja a gyüjteményezés kapcsán felmerülő problémák mütárgyvédelmi és etikai aspektusait is (Fejős, 244-7.). A mai gyüjtést a téma- és problémaközpontúság határozza meg, és ideális esetben együttmüködésben zajlik azokkal, akikre vonatkozik. Ez a participatív gyüjtés stratégiája. „A mai múzeum elképzelhetetlen anélkül, hogy az örökség mibenlétéről, annak folyamatos alakításáról ne ossza meg a felelősség kérdését azokkal, akik »fenntartják «, akiket »szolgál«." (Fejős, 263.) Ez azonban - és ezt Fejős is hangsúlyozza - nem jelenti azt, hogy a múzeumi szakembereknek ne volna felelősségük, hogy mellőzhető volna a szakértelem, a tudományos képzettség. Pusztán kevésbé lesz autoriter a múzeumi működés, és sokkal inkább a partnerségre épít, amivel demokratikusabb müködési modellt próbál érvényesíteni müködésében.

A magyarországi múzeumi jelenkutatást tárgyaló fejezetben Fejős a kortárs dizájn reprezentációjára külön fájó hiányként tér ki. A jelen kötet 2/3-át 2013ban zárta le a szerző. „A kézirat befejezése óta - ahogy Fejős meg is jegyzi - a magyarországi múzeumi szervezet gyökeresen átalakult. (...) A kézirat magyarországi része az átalakulások előtti állapotot rögzíti és elemzi (...)” (Fejös, 8.)

Az Iparművészeti Múzeumban azóta megalakult a Kortárs Dizájn Főosztály, melynek feladata, hogy a múzeum fóépületének rekonstrukciója alatt megalapozzon egy gyüjteményt elsődleges fókusszal az egykori keleti blokk országainak dizájnjára, és hogy minél több közremüködő partnert vonjon be ebbe az folyamatba.

A múzeum új osztálya az állandó forráshiány ellenére több olyan programot is elindított, ami a gyüjteményezést célozza, hisz itt még kevés a tárgy: folyamatos kapcsolatépítést (gyüjtőkkel, alkotókkal, dizájnerekkel, társintézményekkel), egy participatív gyüjteményezési programot, egy konferenciasorozat (Collec_Think Tank) elindítását és egy olyan kiállítássorozatot (Körforgásban), melynek ötletét edukációs, gyüjteményezési, gyüjteménymenedzsmenti és stratégiai célok inspirálták. A feladat nagy: egyszerre kell néhány év alatt felelősen és szakmailag 
megalapozni egy gyüjteményt, pótolni legalább hetven évnyi lemaradást, ugyanakkor olyan programot nyújtani, ami egyszerre nevel közönséget, és vezet fel egy reményeink szerint néhány év múlva megnyíló, a jelen problémáira érzékeny, érvényes tartalmakkal teli múzeumot.

Fejős könyve kiegyensúlyozott, józan hangvételü mủ. Fontos szakirodalom a mai múzeumi szakma számára, melyben a visszafogott enigmatikus cím mellett talán csak egy fél mondat az egyetlen személyes elem, amit megenged magának a szerző: „(...) az »igazi« múzeumhoz - amiben mindannyian hittünk, de amit legelőször is magunkban építünk" (Fejös, 9.).

Fejős, minden szerénység nélkül és joggal jegyzi meg, hogy az utóbbi években a múzeumi kutatások terén az újító megoldásokat kereső, a nemzetközi színtéren is releváns problémákkal foglalkozó Néprajzi Múzeum dolgozói élen jártak a hazai múzeumok között. Az egykori kollégák attitűdje azóta sem változott, mely okot ad a reményre, hogy a befektetett energia, az elvégzett munka nem volt hiábavaló, és a jó gyakorlatok tovább élnek. Fejős a záró fejezetben így ír: „Mivel új terepen mozgunk, az értelmezéshez, a megértéshez új metaforák is kellenek. (...) talán termékenyebb, ha a jelen belső tartalmát próbáljuk letapogatni, ha fogalmán gondolkodunk, mint hogy rögzült sémákat kövessünk. Szabadítsuk ki a jelent a múlt retorikus fogságából!" (300.)

Az új helyek fizikailag is épülnek, és remélhetőleg össze fognak kapcsolódni az új metaforákkal, melyek együttmüködésekből, közös gondolkodás eredményeként tudnak megszületni. Bízzunk abban, hogy az ,igazi” múzeumot nemcsak magunkban, de egyre inkább csapatban, közösen építjük.

(Fejös Zoltán: Új helyek, új metaforák. Közelitések a jelen múzeumi etnográfiájához. Debreceni Egyetemi Kiadó, Debrecen, 2017, 426 o.)

Horváth Judit Phd, az Iparmúvészeti Múzeum Kortárs Dizájn Fôosztályának vezetője 